\title{
THE FIVE STAGES OF BUSINESS PROCESS MANAGEMENT MATURITY MODEL
}

\section{Ernad Kahrovic}

State University of Novi Pazar, Novi Pazar, Serbia

Nada Vignjevic Djordjevic

State University of Novi Pazar, Novi Pazar, Serbia

OMESTE

JEL Category: M11, 032

\begin{abstract}
Business Process Management (BPM), in diverse forms, has been around for the last 30 years. During this time BPM has progressed to a holistic management approach that has a distinctive level of complexity resulting in part from the infinite of implementation options available. The popularity and significance of BPM lead to the question of how advanced different organizations are in their BPM development. The notion of maturity has been proposed for a number of management approaches as a way to evaluate the fullness or perfection of growth or development. This paper describes business process management as a new paradigm for competitive advantage. Also, the paper presents the five stages of the business process management maturity model that has been developed for the evaluation and advancement of BPM effectiveness across organizations.
\end{abstract}

Keywords: business process management, process maturity, maturity stages

\section{INTRODUCTION}

New technology, a constantly changing marketplace, intense global competition, and the expanded aspirations of workers who are demanding increased participation and greater responsibility are forcing companies to become more efficient each day. There is a very small number of companies which can afford themselves to function in a vacuum; others should optimize their business activities. The very useful way of reducing non-value-added activities is a business process management (BPM) or business process orientation (BPO). It has been

Address of the corresponding author:

Ernad Kahrovic

莑 ekahrovic@np.ac.rs recognized by academicians, consultants, and practitioners as a management philosophy which can assure improved business practice. Although process management has many concepts and ideas, one of the strongest initiatives is a process maturity model. Therefore, a business process management maturity model is a tool that can assist organizations in becoming more successful with BPM, resulting in the achieving of greater operational and business performance benefits. More than 150 maturity models have been developed to measure, among others, the maturity of strategic alignment, innovation management, program management, IT service capability, enterprise architecture, and knowledge management. 


\section{BUSINESS}

\section{MANAGEMENT}

Developing new models of the organization requires a new form of thinking, which will result in radical improvements in business performance. This new way has been typically described as business process management. (Kahrovic, E., \& Krstic, B., 2015). Business process management was recommended thirty years ago by Michael Porter (1985). This author introduced the concept of interoperability across the value chain and horizontal organization as a significant topic within firms. (Porter, 1985). Davenport and Short (1990) also depicted a process management orientation within a company as a crucial component for success in "New Industrial Engineering: Information Technology and Business Process Redesign." They defined process management as a horizontal design of business that cuts across the organization with product inputs at the beginning and outputs and customers at the end. (Krstic, Jovanovic, \& Kahrovic, 2012) They suggested that five major steps in process redesign are (Davenport, \& Short, 1990).: developing the business vision and process objectives, identifying the processes to be redesigned, understanding and measuring the performance of existing processes, identifying IT levers, designing and prototype process. ${ }^{1}$

Furthermore, Hammer and Champy (1993) presented the BPM concept as a vital element of a successful reengineering effort in the most influential business management book "Reengineering the Corporation: A Manifesto for Business Revolution." They offered reengineering as a strategy to overcome the problematic crossfunctional activities that present major performance issues to firms. The apparent conflict between a functional focus ("whom I report to") vs. a horizontal focus ("whom I provide value to") is offered by them as being brought back in balance by adding a BPM to the organization. (Hammer, \&

1 Still, there are many disparate views among practitioners regarding the concept of business processes. Almost all the studied authors define "process" in their own words. There is no single definition which stands out as the most widely used. The differences found between the identified definitions have been reduced to six components that can be seen in the majority of
Champy, 1993) Along with Hammer and Champy, Bryne (1993) among the first popularized the term "horizontal organization" and provided a prescriptive definition of a business processoriented model. (Bryne, 1993, Dec. 13). Also, numerous authors have researched the idea of organizing around business processes in a certain manner. A process-oriented organization is likewise regularly referred to as a "processcentred organization" (Hammer, 1996) "horizontal organization" (Ostroff, 1999), "process enterprise" (Hammer, Stanton, 1999), "process-focused organization" (Gardner, 2004), "process managed organization" (Rummler, Ramias, \& Rummler, 2009).

\section{BPM MATURITY MODELS: LITERATURE REVIEW}

Process maturity recently appeared as a mainstream topic in the business process management literature. The concept is offered as a path to business improvement and success. Its basic notion is that there is a different level of process management orientation and that companies should strive to reach a higher process maturity level. Recently, a number of models to measure the maturity of Business Process Management have been proposed. The basis for the majority of these maturity models has been the Capability Maturity Model developed by the Software Engineering Institute at Carnegie Mellon University. This model was originally developed to assess the maturity of software development processes and is based on the concept of immature and mature software organizations. The basis for applying the model is confirmed by where it is indicated that improved maturity results "in an increase in the process capability of the organization". (Paulk, Curtis, Chrissis, \& Weber, 1993).

Smith and Fingar (2004) argue that a CMM-based maturity model which postulates well-organized

definitions: input and output, interrelated activities, horizontal (intra-functional or cross-functional), purpose or value for customer, the use of resources, and repeatability. A process definition can be condensed to "a horizontal sequence of activities that transforms an input (need) to an output (result) to meet the needs of customers or stakeholders" 
and repeatable processes cannot capture the need for business process innovation. A shortcoming of these BPM models has been the simplifying focus on only one dimension for measuring BPM maturity and the lack of actual applications of these models. (Smith, \& Fingar, 2004) In a similar way, Fisher (2004) combines five "levers of change" with five states of maturity. Pritchard and Armistead (1999) provide an attempt to divide organizations into groups depending on their grade and progression of BPM implementation. Among others, Harmon (2004) developed a BPM maturity model based on the Capability Maturity Model (see also Harmon 2003). Maull et al. (2003), whilst trying to define the maturity of BPR programs, encountered problems that they could not use objective measures. They tried to define BPM using two dimensions, an objective measure (time, team size, etc.) and a "weighting for readiness to change", but this approach turned out to be too complex to measure. Therefore, they chose a phenomenological approach assessing the organization's perception of their maturity, using objective measures as a guideline. The RummlerBrache Group commissioned a study, which used 10 success factors gauging how well an organization manages its key business processes. (Rummler-Brache Group, 2004) The results have been consolidated in a Process Performance Index. Another example of how to define maturity (or in their case "process condition") is provided by DeToro and McCabe (1997), who used two dimensions (effectiveness and efficiency) to rate a process' condition. (DeToro, \& McCabe, 1997).

\section{THE FIVE STAGES OF BUSINESS PROCESS MANAGEMENT MATURITY MODEL}

The comparison of low and high maturity in Figure 1 helps to clarify the comprehensiveness and range of BPMM. The idea of comparing low and high maturity derives from Paulk et al. (1993), who presented such a comparison to facilitate the understanding of the concept of process maturity. The proposed BPMM model adopts the five maturity stages to differentiate various levels of sophistication of a BPM initiative. (Paulk, Curtis, Chrissis, \& Weber, 1993)

An organization with a BPMM at Stage 1 will have made either no or very uncoordinated and unstructured attempts towards BPM. Typically, such an organization may display some combination of the following characteristics: ad hoc approaches, limited scope of BPM initiatives, various and non-consolidated approaches to methodology, tools and techniques, individual efforts (IT or business), minimal employee involvement, low reliance on external BPM expertise and high level of manual interventions and work around.

\begin{tabular}{|c|c|c|}
\hline Low Maturity & & High Maturity \\
\hline Un-coordinated, isolated projects & & Co-ordinated BPM Activities \\
\hline Low BPM Skills & 5. Optimised & High BPM Expertise \\
\hline Key Personnel & & Organisational Wide Coverage \\
\hline Reactive & 4. Managed & Proactive \\
\hline Manual & 3. Reneata & (Meaningful) Automation \\
\hline Internally Focused & 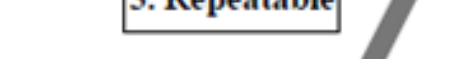 & Extended Organisation \\
\hline Low Resourcing & 2. Defined & Efficient Resourcing \\
\hline Naive & & Comprehensive Understanding \\
\hline Static & 1. Initial State & Innovative \\
\hline
\end{tabular}

Figure 1 - Comparison of low and high maturity and the five-maturity stage

An organization with a BPMM at Stage 2 will have progress past making first BPM experiences and will be starting to build up BPM capability and increasing the number of people who look at the organization from a process perspective. Typically, such an organization may display some combination of the following characteristics: first documented process, recognition of the 
importance of BPM, increased involvement of executives and top management, one main purposes for exploring BPM, extensive use of simple process modeling with simple repositories, first attempts with a structured methodology, common standards and increased reliance on external BPM expertise. (Jeston, \& Nelis, 2009)

An organization with a BPMM at Stage 3 will experience increased momentum in its quest to develop BPM capability and expand the number of people looking at the organization from a process perspective. Typically, such an organization may display some combination of the following characteristics: focus on the management of the early phases of the process lifestyle, use of elaborate tools (e.g. dynamic modeling, serverbased applications, multiple and distributed users), a combination of different process management methods and tools (e.g. process redesign, workflow management and processbased risk management), more extensive use of technology for delivery and communication of BPM, comprehensive and formal BPM training sessions and less reliance on external expertise.

An organization with a BPMM at Stage 4 will enjoy the benefits of having BPM firmly entrenched in the strategic make-up of the organization. Typically, such an organization may display some combination of the following characteristics: an established Process Management Center of Excellence that maintains standards, exploration of business process controlling methods and technologies, merging IT and business perspectives on process management, formal, designated process management positions, widely accepted methods and technologies, integrated process management purposes, process orientation as a mandatory project component, continuous extension, and consolidation of process management initiatives and minimal reliance on external expertise.

An organization with a BPMM at Stage 5 will enjoy the benefits of having BPM firmly entrenched as a core part of both strategic and operational management within the organization. Typically, such an organization may display some combination of the following characteristics: process management is a part of managers' activities, accountabilities and performance measurements, wide acceptance and use of standard methods and technologies, oneorganization-wide approach to BPM that incorporate customers, suppliers, distributors, and other stakeholders, establishes business process lifecycle management and Business Process Management Center of Excellence reduces size as process management become simply the way business is done.

\section{CONCLUSION}

This paper has provided a brief and selective overview of the structure and components included in a holistic and contemporary model that facilitates the assessment of the business process management maturity model. The actual BPMM assessment derived by applying this model can occur on various level. In future, it is necessary to conduct a number of case studies with European, American and Australian organizations, in order to develop a deeper understanding of the requirements related to a BPMM assessment and to get further feedback on the appropriateness of the proposed model.

\section{WORKS CITED}

Bryne, J. A. (1993, December 13). The Horizontal Corporation. Business Week, pp. 76-81.

Davenport, T. H., \& Short, J. (1990). The New Industrial Engineering: Information Technology and Business Process Redesign. Sloan Management Review, 31(4), 11-27.

DeToro, I., \& McCabe, T. (1997). How to Stay Flexible and Elude Fads. Quality Progress, 30(3), 55-60.

Fisher, D. M. (2004, Sept.). The Business Process Maturity Model. A Practical Approach for Identifying Opportunities for Optimization. Business Process Trends.

Gardner, R. (2004). The Process - Focused Organization. Milwaukee, WI: Quality Press.

Hammer, M. (1996). Beyond Reengineering: How the Process - Centred Organization Is Changing Our Work and Our Lives. New York, NY: Harper Collins Publishers. 
Hammer, M. H., \& Champy, J. (1993). Reengineering the Corporation: A Manifesto for Business Revolution. New York, NY: Harper Business.

Hammer, M., \& Stanton, S. (1999). How Process Enterprises Really Work. Harvard Business Review, 77(6), 108-118.

Harmon, P. (2003). Business Process Change: A Manager's Guide to Improving, Redesigning, and Automating Processes. Morgan Kaufmann Publishers.

Harmon, P. (2004, March). Evaluating an Organization's Business Process Maturity. Business Process Trends.

Jeston, J., \& Nelis, J. (2009). Business process management: Practical Guidelines to Successful Implementation. Elsevier.

Kahrovic, E., \& Krstic, B. (2015). The effects of business process management on the improvement of firm performances, Industrija, 43(4), 67-87.

Krstic, B., Jovanovic, S., \& Kahrovic, E. (2012) process-oriented enterprise management as a determinant of organizational behavior in contemporary business terms. Actual Problems of Economics, 11(137), 369-380.

Maull, R. S., Tranfield, D. R., \& Maull, W. (2003). Factors characterizing the maturity of BPR programmes. International Journal of Operations \& Production Management, 23(6), 596 - 624.

Ostroff, F. (1999). The Horizontal Organization. New York, NY: Oxford University Press.

Paulk, M. C., Curtis, B., Chrissis, M. B., \& Weber, C. V. (1993). The Capability Maturity Model for Software, Version 1.1. (No. CMU/SEI-93-TR-24): Software Engineering Institute.

Porter, M. E. (1985). Competitive Advantage: Creating \& Sustaining Superior Performance. New York, NY: The Free Press.

Pritchard, J. P., Armistead, C. (1999). Business process management - lessons from European business. Business Process Management Journal, 5(1), 10 - 32.

Rosemann, M., \& de Bruin, T. (2005, Febr.). Application of a Holistic Model for Determining BPM Maturity. Business Process Trends.

Rummler, G. A., Ramias, A., \& Rummler, R. A. (2009). White Space Revisited: Creating Value Through Process. San Francisco, CA: Pfeiffer.

Rummler-Brache Group (2004). Business Process Management in U.S. Firms Today. A study commissioned by Rummler-Brache Group. March 2004.

Smith, H., \& Fingar, P. (2004, July). Process Management Maturity Models. Business Process Trends.

Received for publishing: 23.02 .2018

Revision received: $\quad$ 03.09.2018

Accepted for publication: 10.07.2019

\section{How to cite this article?}

Style - APA Sixth Edition:

Kahrovic, E., \& Djordjevic, N. V. (2019, July 15). The Five Stages of Business Process Management Maturity Model. (Z. Cekerevac, Ed.) MEST Journal, 7(2), 49-54. doi:10.12709/mest.07.07.02.06

Style - Chicago Sixteenth Edition:

Kahrovic, Ernad, and Nada Vignjevic Djordjevic. 2019. "The Five Stages of Business Process Management Maturity Model." Edited by Zoran Cekerevac. MEST Journal (MESTE) 7 (2): 4954. doi:10.12709/mest.07.07.02.06. 
Style - GOST Name Sort:

Kahrovic Ernad and Djordjevic Nada Vignjevic The Five Stages of Business Process Management Maturity Model [Journal] // MEST Journal / ed. Cekerevac Zoran. - Belgrade - Toronto : MESTE, July 15, 2019. - 2 : Vol. 7. - pp. 49-54.

Style - Harvard Anglia:

Kahrovic, E. \& Djordjevic, N. V., 2019. The Five Stages of Business Process Management Maturity Model. MEST Journal, 15 July, 7(2), pp. 49-54.

Style - ISO 690 Numerical Reference:

The Five Stages of Business Process Management Maturity Model. Kahrovic, Ernad and Djordjevic, Nada Vignjevic. [ed.] Zoran Cekerevac. 2, Belgrade - Toronto : MESTE, July 15, 2019, MEST Journal, Vol. 7, pp. 49-54. 